\title{
REVIEW
}

\section{A BRIEF REVIEW OF THE SCIENCE EDUCATION ACTIVITIES OF NARESA/NSF OVER TWENTY FIVE YEARS}

\author{
U.M. SENANAYAKE \\ Industrial Technology Institute, Bauddhaloka Mawatha, Colombo 7
}

Received: 07 April 1998 ; accepted: 09 April 1999)

\begin{abstract}
The Science Education Research Committee was established by National Science Council in May 1976. This paper reviews activities of this Committee with special reference to publications and public awareness seminars. It lists 8 research projects for which funds were provided.
\end{abstract}

Key words: Science education

\section{INTRODUCTION}

Prior to 1968, i.e. before the establishment of the National Science Council (NSC) both science education and the publication of an edited Science Journal was done by the then Ceylon Association for the Advancement of Science, now called Sri Lanka Association for the Advancement of Science (SLAAS). These activities were carried out by a sub committee called the Committee for the Popularisation of Science (CPS). It was not a funding organisation, but rather a Committee organising various science education seminars for school children. The scientific journal called Vidya Vyapti, is published quarterly by CPS in Sinhala. These activities are carried out even today by the CPS.

The other national body, the former Chemical Society of Ceylon, now called the Institute of Chemistry, Ceylon, also carried out limited activities in the area of science education. There were seminars organised both for school children and the public. The Institute of Chemistry, Ceylon publishes a magazine containing abstracts of papers presented at its annual sessions in Sri Lanka as well as other articles in chemistry.

The Science Education Research Committee was established by the NSC in May 1976. The initial mandate of this committee was to co-operate in research programmes with the Ministry of Education, on thirty high priority areas in science education. In June 1982, the National Science Council (NSC) was renamed as Natural Resources, Energy and Science Authority (NARESA) of Sri Lanka, by Act 78 of 1981.

The six statutory Working Committees and the six specialist Panels of the NSC were replaced with ten statutory Working Committees. The Science 
Education Research Committee was one of them. This Committee is now called the Steering Committee on Science Education.

'Vidurava' the science bulletin of NSC which was launched as a multilingual quarterly publication for the dissemination of current science information, came under this committee's purview.

Some of the early activities of the Steering Cornmittee on Science Education were:

(a) The launching of Vidurava, a popular science journal, in 1976.

(b) Conducting a full time training course on science education research planning, methodology ana report writing in December 1980.

(c) Initiation of a new publication titled Science Investigations. The first issue was released in 1981 .

(d) Publication of the science education supplementary reading material series. The first two publications were released in 1981.

(e) Establishment of the Sri Lanka Association of Science and Mathematics Education (SLSME). The inaugural meeting was convened in December 1984.

(f) Conducting a seminar on Problems and Issues in Higher Education in August 1990.

(g) Holding a workshop on scientific writing in September 1991.

\section{Major areas of funding}

A total of Rs. 502,160/- was given for eight research grants on Science Education. These grants were:

(i) $\mathrm{RG} / 90 / \mathrm{SE} / 01$ - Study skills of GCE (A/L) science students - an attempt at their identification (Rs. 5,000/-).

(ii) RG/91/SE/01 - Scientific literacy in Sri Lanka's population groups/ prevalence, social, educational and administrative significance (Rs. 84,000)

(iii) RG/92/SE/01 - Development of mathematical concepts of weak children \& remedies to achieve their target by doing research ( $\mathrm{Rs}_{\mathrm{s} .10,000)}$

(iv) RG/93/SE/01 - Role of the primary teacher in constructing instructional strategies in environmental studies for upper primary students. A sritical 
review with special reference to Sri Lanka (Rs. 54,000/-) Mrs. R.M: Premaratne ( Open University, Sri Lanka) PhD pending

(v) RG/93/SE/02 - Critical evaluation of the G.C.E. (A/L) syllabus in schools in Sri Lanka (Rs. 19,000/-)

(vi) RG/95/SE/01 - Principal's leadership qualities that contribute to teacher motivation and loyalty with special reference to science education (Rs. 15,000/-) - Mrs. A.M. Hettige, University of Colombo, M.Phil

(vii) RG/95/SE/02 - Development of a suitable teaching method on environmental pollution for tertiary level education ( $\mathrm{Rs} .292,000 /-$ ) ( a booklet is being prepared on laboratory safety)

(viii) Study on the attitudes towards science of secondary school students of Sri Lanka (with special reference to the Galle district (Rs. 22,960/-) Mrs. N.A. Amarasinghe, University of Colombo, M.Phil

As the research activities were started after 1990s and the final reports were received by NARESA after 1993, the translation of findings into applications are still under review.

\section{Steering committee activities}

The Steering Committee on Science Education and the Editorial Board of Vidurava carried out many activities indicated below.

i. Holding public awareness seminars

ii. Science investigations and publications

iii. Guidance for the publication of Vidurava

iv. Holding seminars and workshops on popular science writing and training

v. Guidance for the publication of the science education series

vi. Selection of grantees and monitoring their progress on primary and secondary science education and environmental studies 


\section{Public awareness seminars}

These seminars were held to educate the general public and particularly the school children. Topics were chosen to suit their needs. The topics chosen were :
a. Food and nutrition
b. Maternal nutrition
c. Climate change and environment
d. Environmental conservation
e. Landslides
f. $\quad$ AIDS and social issues
g. First Aid

The speakers for each topic were chosen carefully. They not only had a sound knowledge of the subject, but also were able to explain matters carefully and clearly in Sinhala. The target audience was both general public and school children. Seminars on 'Food and Nutrition' were held in many parts of Colombo city, particularly on requests made by both private and public sector organisations. The targeted group for the seminars on 'Maternal Nutrition' was expectant mothers. These seminars were held at the Castle Street Maternity Hospital and Kalutara National Health Services Centre.

Seminars on 'Climate change and Environment', 'Environmental Conservation' and Landslides' were held in areas such as Central Province area prone to landslides. The other seminars were held both in the Colombo district and places in Polonnaruwa, Uva, Sabaragamuwa, Monaragala and Kalutara districts. AIDS and social issue seminar was directed to general public and social workers. The main activity centre was at Kalutara Health Education Centre. For most of the above seminars, the key medical and educational officers attended either as speakers or observers.

\section{Science investigations and publications}

Some school children have done useful investigations both in environmental and biological studies. The results are important and need publication. Vidurava has allocated space for such publications. Students and teachers of secondary schools are aware of this facility. The material before publishing is edited by the Vidurava editorial board. Proceedings of such workshops and prize winning essays are considered for publication.

Vidurava is the official popular science journal of NARESA. It is published quarterly both in English and Sinhala. There is an official Editor. The publication is closely monitored by the Science Education committee. The topic for each issue is 
selected by the committee. It could be on a popular single topic or a collection of articles from various disciplines. For example some of the topics published in recent Vidurava issues are Vol. 14 No.2 (1992.) 'Aquatic weeds' No. 3 \& 4 (1992) 'Food and well being', Vol. 16 No.1/2 (1994), 'Family health' Vol.3/4(1994) 'War and peace' Vol, 17 No.1/2 (1995) Medicinal plants of Sri Lanka, No.18 No. 1/2 (1996) 'The Library then and now'.

Prof. Nandadasa Kodagoda was an active member and a past chairman of the committee on Science Education and Editorial Board of Vidurawa. He passed away in 1997. As a token of appreciation for his contributions, a special issue of Vidurava Vol. 19 No. 2 was dedicated to him and was called 'Prof. Nandadasa Kodagoda memorial issue'.

It is interesting to note that Vidurava Vol.3/4 (1994) 'War and peace' is a collection of articles from well known writers in the field as well as prize winning articles from essay contests written by four school children. Vidurava is posted to many schools in the island. The general public can buy copies from the NARESA office. So far 18 volumes have been published.

Holding seminars and workshops in Popular Science Writing is an activity recently launched by the steering committee on Science Education, largely due to the efforts of late Prof. Nandadasa Kodagoda. These workshops and seminars have been aimed at training young writers in the field of journalism and electronic media. The participants were young writers and media persons selected from main newspaper groups and electronic media. The participants were exposed to lectures and workshops conducted by well known media persons. They were given training in both theoretical and practical aspects of journalism. As a result of this activity they formed an association called 'Young Science Writers Association' and their activity continues.

The Science Education committee is also conducting seminars and workshops for the mature participants selected from various research organisations in the field of science writing. As such, a workshop was held on $10-11^{\text {th }}$ May 1996 where participants from 16 organisations participated.

\section{Science education series}

These are booklet form publications. Each topic is selected by the Science Education committee. A suitable writer having both qualifications and ability to write on the topic is given the responsibility to write on the topic. Some of the topics written in this series are, 'Mineral nutrition of plants', 'Food spoilage and food preservation', 'Limestone resources in Sri Lanka'. Some of the topics are written in Sinhala. At the moment over 36 topics have been published. 


\section{Selection of grantees to carry out research in science education}

Science Education committee also entertains research grant appicctions on suitable topics of national interest.

Grantees send half yearly progress reports. The Steering Committee closely monitors the progress of the grant aided project. If necessary the grantee is called up periodically to explain any areas. After the project is completed, the grantee sends the final project report to the Committee.

Annually one or two grants are made, depending on the availability of funds. Sri Lanka Association for the Advancement of Science (SLAAS) through its Committee for the Popularisation of Science (CPS) conduct similar work. Though it is not a funding agency, CPS carries out science day programmes in schools in various parts of the island. These are similar to science awareness programmes conducted by the Science Education committee of NARESA. CPS also publishes a half yearly magazine called Vidya Vyapthi similar to Vidurava. It also conducts a nature diary programme annually in schools in selected districts. This is a three month programme where Grade 9 students have to keep a Nature diary. NARESA does not conduct such a programme. These activities are also mentioned in the introduction.

As far as the infrastructure for scientific research is concerned. Steering Committee does not carry out any research activity except for monitoring the progress of research undertaken by grantees in the field of science education.

The Committee has endeavoured to collect traditional scientific knowledge in the field and has published a science education monograph ( $\mathrm{SE}, \mathrm{No}_{0} 36$ ) under the heading 'Scientific principles seen in ancient artifacts and monumental structure'.

Regarding the future developments and needs in the field by science education in the country the following can be highlighted.

(a) Public awareness seminars should be conducted regularly and more often. The topics should be expanded. The target audience should be school children and the general public, particularly in the rural areas.

(b) Efforts should be taken to popularise the Vidurava bulletin and the science education series. A general survey conducted by the Steering Committee revealed that many school children are unaware that such publications exit. School children should be encouraged to contribute articles to Vidurava.

(c) Results of the research projects carried out by the grantees shouid be made available to interested persons. 